\title{
Peak Responses during Exercise Treadmill Testing using Individualized Ramp Protocol and Modified Bruce Protocol in Elderly Patients
}

\author{
Sergey Kozlov ${ }^{1}$, Martin Caprnda ${ }^{2}$, Olga Chernova ${ }^{1}$, Marina Matveeva ${ }^{1}$, Irina Alekseeva ${ }^{1}$, Katarina \\ Gazdikova $^{3}$, Ludovit Gaspar², Peter Kruzliak ${ }^{4}$, Slavomira Filipova ${ }^{5}$, Zufar Gabbasov ${ }^{1}$ \\ ${ }^{1}$ National Medical Research Centre of Cardiology, Ministry of Health, Moscow, Russian Federation \\ ${ }^{2}$ Department of Internal Medicine, Faculty of Medicine, Comenius University and University Hospital, Bratislava, Slovak Republic \\ ${ }^{3}$ Department of Nutrition, Faculty of Nursing and Professional Health Studies, Slovak Medical University, Bratislava, Slovak Republic \\ ${ }^{4}$ Laboratory of Structural Biology and Proteomics, University of Veterinary and Pharmaceutical Sciences, Brno, Czech Republic \\ ${ }^{5}$ Department of Cardiology, National Institute of Cardiovascular Diseases and Slovak Medical University, Bratislava, Slovak Republic
}

Corresponding author: Peter Kruzliak, Laboratory of Structural Biology and Proteomics, University of Veterinary and Pharmaceutical Sciences, Palackeho tr 1946/1, Brno 61242, Czech Republic; E-mail: peter.kruzliak@savba.sk; Tel.: +420543181111

Received: 26 Jan 2019 Accepted: 18 July 2019 Published: 31 March 2020

Citation: Kozlov S, Caprnda M, Chernova O, Matveeva M, Alekseeva I, Gazdikova K, Gaspar L, Kruzliak P, Filipova S, Gabbasov Z. Peak responses during exercise treadmill testing using individualized ramp protocol and modified Bruce protocol in elderly patients. Folia Med (Plovdiv) 2020;62(1):76-81. doi: 10.3897/folmed.62.e49809.

\begin{abstract}
Background: Exercise capacity is well known to be an important prognostic factor in patients with cardiovascular disease and among healthy persons.

Aim: To determine if there are any differences between the peak exercise response during exercise treadmill testing with the individualized ramp protocol and the modified Bruce protocol in elderly patients.

Materials and methods: The study included 40 patients (both male and female), aged 70 years and older, who had not had a baseline history of the confirmed coronary artery disease or heart failure diagnoses. All patients underwent exercise treadmill testing using modified Bruce protocol and individualized ramp protocol for 2 consecutive days. Peak heart rate, peak systolic and diastolic blood pressure, peak pressure-rate double product, exercise duration, and peak metabolic equivalents were recorded in both tests. Perceived level of exertion was evaluated using the Borg 10-point scale.
\end{abstract}

Results: The average duration of exercise was longer for the ramp protocol than for the modified Bruce protocol. When the modified Bruce protocol was used, patients achieved a lower workload than they did in using the ramp protocol. The rating of perceived exertion using the revised Borg scale ( 0 to 10 ) was $5.6 \pm 1.4$ for the ramp protocol and $8.7 \pm 1.4$ for the modified Bruce protocol, which indicates that the patients found the ramp protocol easier.

Conclusion: In elderly patients the individualized ramp treadmill protocol allows to achieve the optimal test duration with higher degrees of workload and greater patient comfort during the test more often than does the modified Bruce protocol.

\section{Keywords}

elderly adults, exercise treadmill testing, exercise capacity, individualized ramp protocol, modified Bruce protocol,

Copyright by authors. This is an open access article distributed under the terms of the Creative Commons Attribution License (CC-BY 4.0), which permits unrestricted use, distribution, and reproduction in any medium, provided the original author and source are credited. 


\section{INTRODUCTION}

Exercise capacity is well known to be an important prognostic factor among patients with cardiovascular disease as well as in healthy people. ${ }^{1-3}$ The direct measurement of oxygen use (peak oxygen uptake) as measured during cardiopulmonary exercise testing provides the most accurate noninvasive quantification of maximal aerobic capacity. ${ }^{3}$ Metabolic equivalents (METs) achieved during exercise testing are a surrogate indicator of exercise performance that are calculated from workload and often used as an alternative to cardiopulmonary exercise testing when ventilatory expired gas analysis is not available..$^{2,4,5}$ Selection of an appropriate protocol for the exercise capacity assessment is of crucial importance. ${ }^{4,5}$ A correctly chosen protocol of exercise testing provides for linear relationship between exercise volume and consumed oxygen volume, as well as between heart rate and consumed oxygen volume. The protocol should be individually tailored to yield fatigue-limited exercise duration of 8-12 min. ${ }^{2}$ Shorter durations may produce a nonlinear relationship between consumed oxygen volume and work rate, whereas durations $>12$ min may cause patients to terminate exercise because of muscle fatigue or orthopedic factors.

Exercise capacity in older adults is an important indicator of health status. ${ }^{6}$ However, increasing frailty and other limitations that accompany aging are common barriers to exercise stress testing. ${ }^{2,7}$ Thus, the test modality and protocol should be carefully selected to optimize performance and safety and to ensure meaningful assessment despite physical limitations. There are a number of standardized protocols used for exercise treadmill testing. ${ }^{2}$ The recommendations according to which specific protocols should be used to assess exercise capacity in older adults are lacking. The Bruce protocol is the most common protocol for exercise treadmill testing. It is used in $66 \%$ of all the routine clinical tests performed. ${ }^{3}$ However, the Bruce protocol contains large and unequal work increments between stages, resulting in a nonlinear relationship between physiologic responses and work rate, which is even more pronounced among older adults. The modified Bruce protocol is better tolerated by patients, but it has the same shortcoming as the original protocol meaning the large and unequal work increments. The use of these protocols may lead to early termination of test. However, other types of the protocol, such as ramp protocol with small continuous increases in workload during exercise testing ${ }^{8-10}$, are more preferable when testing older adults. In addition, the ramp protocol can be individualized which may be particularly important when testing older adults. The relevant data on the use of individualized ramp protocol are lacking, as well as the comparison of peak exercise response during exercise treadmill testing with individualized ramp protocol and with commonly used protocols in older adults. The purpose of this study was to compare individualized ramp protocol and modified Bruce protocol to determine if there are any dif- ferences in the peak exercise response in patients aged 70 years and older.

\section{MATERIALS AND METHODS}

The study included 40 patients of both genders, 70 years of age or older, who did not have a baseline history of established coronary artery disease (CAD), typical angina or heart failure. Individuals with the established CAD were defined as those with a history of myocardial infarction, angiographically documented coronary artery disease, coronary angioplasty, coronary artery bypass surgery, or an abnormal result on an exercise test that was suggestive of coronary artery disease (horizontal or down slopping ST-segment depression of $\geq 1.0 \mathrm{~mm}$ ). Typical angina, atypical angina or non-anginal chest pain were identified based on the characteristics of chest pain. ${ }^{11}$ Patients with uncontrolled arterial hypertension, atrial fibrillation or flutter, hypertrophic and dilated cardiomyopathy, valvular heart disease, cerebrovascular disease (history of stroke, transient ischemic attacks, or carotid artery surgery), musculoskeletal impairment (lower extremity arthritis that significantly impaired walking), which were not able physically to safely complete a full treadmill exercise, or had contraindications ${ }^{2}$ to the exercise test were not included in the study. Patients were also not included in the study if their baseline ECG at rest exhibited ST-T changes or conduction abnormalities $^{12,13}$ which did not allow to correctly interpret stress test results.

This study was approved by the Ethic Committee of the National Medical Research Centre of Cardiology. After the written informed consent was obtained, patients underwent symptom-limited treadmill testing which included two different protocols: the standardized modified Bruce protocol ${ }^{2}$ and the individualized ramp treadmill protocol. The first tested protocol was randomly distributed between patients. Both stress tests were performed within 2 consecutive days. The order of the tests for each patient was randomly determined by drawing lots. The individualized ramp protocol was designed based on age, gender, and weight. The predicted values of $\mathrm{VO}_{2 \max }(\mathrm{ml} / \mathrm{min})$ were calculated using the formulas: $[50.72-(0.372 \times$ age $)] \times$ weight $\times 1.1$ for men, and $[22.78-(0.17 \times$ age $)] \times($ weight +43$) \times 1.1$ for women. ${ }^{14}$ The predicted peak exercise capacity in MET was calculated by dividing the received values by (weight $\times 3.5$ ). We assumed that tests should last $10 \mathrm{~min}$. The participants started walking on the treadmill at $1.6 \mathrm{~km} / \mathrm{h}$ and an incline of 0 percent. The speed and treadmill incline linearly increased until their maximum values were achieved. The maximum speed was chosen to be $4.0 \mathrm{~km} / \mathrm{h}$ for men aged 70-79 years, and $3.2 \mathrm{~km} / \mathrm{h}$ for other patients. The maximum treadmill incline was chosen from the table based on the maximum speed and $\mathrm{VO}_{2 \max }{ }^{15}$ The maximum treadmill incline was $12.5 \%$ for men aged $70-79$ years, $12 \%$ for men aged $80-89$ 
years, $10 \%$ for women aged $70-79$ years, and $7 \%$ for women aged $80-89$ years.

The patients were exercised on InterTrack treadmill (Schiller AG, Switzerland). The two exercise tests were performed during the late morning hours. The patients had been asked to abstain from food, coffee, and cigarettes for at least 3 hours before the study and had been instructed to continue their usual medications except beta-blockers which had been discontinued at least $48 \mathrm{~h}$ before the exercise testing. The 12-lead ECG was being monitored continuously during exercise. The ST-segment depression was assessed visually. The patients were exercised to their self-determined maximal capacity or until the physician stopped the test after the target heart rate had been achieved (that was at least $85 \%$ of the age-predicted value). The test was also terminated in case of moderately severe chest pain, severe arrhythmia, undue rise in blood pressure, or $\geq 1 \mathrm{~mm}$ horizontal or down sloping ST depression, measured 80 ms after the J point. Age-predicted peak exercise heart rate was calculated using the formula: $208-(0.7 \times a g e) .{ }^{16}$ Resting and peak heart rate and systolic and diastolic blood pressure were recorded. Peak pressure-rate double product was calculated for each test. Exercise duration, peak METs, and perceived level of exertion were recorded for both tests. Exercise capacity (in METs) was estimated on the basis of exercise time via a commonly used equation for the Bruce protocol and based on American College of Sports Medicine equations for the ramp protocol. ${ }^{3,17}$ Perceived level of exertion was assessed on the revised Borg 10-grade scale. ${ }^{18}$

\section{Statistical analysis}

Statistical analysis was performed using Statistica 10 (StatSoft). Continuous variables are presented as mean and standard deviation, and categorical variables are expressed as absolute and relative frequencies (\%). The normality of the distribution of the variables was confirmed by the Shapiro-Wilk's test. The inter-test comparison of the quantitative variables was performed using the Wilcoxon signed rank test. The level of significance in all the tests performed was $\mathrm{p}<0.05$.

\section{RESULTS}

Baseline characteristics of the study population were as follows: there were 20 men (50\%) of the 40 patients undergoing exercise testing; the mean age of the study sample was 75 years. All of the patients had arterial hypertension and dyslipidemia, $27 \%$ of patients had a history of type 2 diabetes mellitus, $30 \%$ of patients had a family history of $\mathrm{CAD}$, and $17 \%$ of patients were current smokers. The main reasons for a referral to an exercise testing were atypical angina (50\% of patients), non-anginal chest pain (20\% of patients) and shortness of breath (30\% of patients).
The data for both stress tests are presented in Table $\mathbf{1 .}$ For the modified Bruce and the ramp protocols, mean resting heart rate, systolic blood pressure, and diastolic blood pressure were equivalent before the commencement of each stress test. Mean maximal heart rate, maximal systolic blood pressure, maximal diastolic blood pressure, and maximal double product showed no difference between the modified Bruce and the ramp protocols. All of the patients achieved the target heart rates in both protocols. Mean duration of exercise was longer for the ramp than for the modified Bruce protocol (9.2 \pm 0.7 vs $2.4 \pm 0.1 \mathrm{~min}$; $\mathrm{p}<0.001)$. Patients achieved a lower workload with the modified Bruce protocol as compared to the ramp protocol $6.1 \pm 0.5$ vs $3.5 \pm 0.7$ METs; $\mathrm{p}<0.001)$. The rating of perceived exertion from the revised Borg scale (0 to 10 ) was $5.6 \pm 1.4$ for the ramp protocol and $8.7 \pm 1.4$ for the modified Bruce protocol $(\mathrm{p}<0.01)$, indicating that the patients found the ramp protocol easier. Forty five percent of patients rated the intensity of their exercise with the ramp protocol as easy (Borg score of 1-4) and 55\% as moderate (Borg score of 5-7). Thirteen percent of patients rated the intensity of their exercise with the modified Bruce protocol as moderate and $87 \%$ as hard (Borg score of 8-10).

\section{DISCUSSION}

Table 1. Stress test results

\begin{tabular}{lccc}
\hline Characteristic & $\begin{array}{c}\text { Modified } \\
\text { Bruce } \\
\mathbf{n}=\mathbf{4 0}\end{array}$ & $\begin{array}{c}\text { Ramp } \\
\text { protocol } \\
\mathbf{n = 4 0}\end{array}$ & $\begin{array}{c}\mathbf{p} \\
\text { value }\end{array}$ \\
& & & \\
\hline Heart rate & & & \\
Resting heart rate (beats/ & $75 \pm 6$ & $74 \pm 8$ & - \\
min) & & & \\
Maximum heart rate & $124 \pm 3.8$ & $123 \pm 5$ & - \\
(beats/min) & & & \\
Blood pressure & $126 \pm 11$ & $125 \pm 10$ & - \\
Resting SBP (mm Hg) & $76 \pm 9$ & $79 \pm 8$ & - \\
Resting DBP (mm Hg) & $187 \pm 28$ & $186 \pm 28$ & - \\
Maximal SBP (mm Hg) & $101 \pm 7$ & $99 \pm 14$ & - \\
Maximal DBP (mm Hg) & $221 \pm 4$ & $212 \pm 4$ & - \\
Maximal double product & $2.4 \pm 0.1$ & $9.2 \pm 0.7$ & $<0.001$ \\
Exercise duration (min) & $2.5 \pm 0.7$ & $6.1 \pm 0.5$ & $<0.001$ \\
MET achieved & $3.5 \pm 1.4$ & $5.6 \pm 1.4$ & $<0.01$ \\
\hline Borg rating & $8.7 \pm 1.4$ & & \\
\hline
\end{tabular}

Continuous variables shown as median \pm standard deviation. $\mathrm{P}$ value (if $<0.05$ ) shown for variance across protocols.

DBP: diastolic blood pressure; SBP: systolic blood pressure; METs: metabolic equivalents. 
Available data in older adults, although limited, suggest similar prognostic value of exercise testing in this age group to those in younger patients. Among the variables, which may be obtained during ECG exercise testing beyond ST-segment depression, exercise capacity is the most powerful variable that adds to the prognostic utility. ${ }^{19}$ There is a strong inverse and independent association between exercise capacity of individuals and major cardiovascular and overall mortality risk regardless of documented cardiovascular disease. ${ }^{20-25}$ In male patients aged $>70$ years, who achieved $>5.0$ METs, the adjusted hazard ratio for mortality risk over 8 years of median follow-up was $45 \%$ lower compared to those who achieved $\leq 4$ METs. ${ }^{25}$ Selection of an appropriate protocol for the exercise capacity assessment is of crucial importance. ${ }^{4,5}$ It is generally assumed that in order to achieve exercise duration of 8 to 12 minutes older adults' protocols should employ low starting work rates and smaller workload increments, than those for younger patients. $^{2}$ The ramp protocol in which the work rate increases in a constant and continuous manner has gained popularity in recent years, and it is an alternative approach to incremental exercise testing. Both individualized ${ }^{8-10,26,27}$ and standard ramp tests ${ }^{28,29}$ have been used. The former individualize the rate of increase in intensity based on the patient, and the latter match work rates to equivalent time periods as in commonly used protocols but have an increase in ramp fashion. It may be supposed that ramp protocols, especially individualized, would improve an individual's ability to reach $\mathrm{VO}_{2 \max }$. It is so because the ramp increases in work rate are performed in a much more continuous fashion than step increases in work rate used in traditional treadmill protocols.

Our study was aimed at determining peak exercise response to a standard step and individualized ramp fashion increase in workload during a sub-maximal exercise treadmill testing in patients aged $\geq 70$ years, and thus to verify the hypothesis that the individualized ramp protocol is more suitable for older adults. Exercise treadmill testing among those patients using the individualized ramp protocol allowed them in most cases to achieve the predicted peak exercise capacity with optimal exercise duration of 8 to 12 minutes. When using the individualized ramp protocol the achieved duration of the exercise was significantly lower compared to the modified Bruce protocol. Accordingly, patients experienced greater levels of discomfort with the modified Bruce protocol. Thus, the results of our study suggest that in patients aged $\geq 70$ years the individualized ramp protocol is to some extent more preferable for exercise treadmill testing than the commonly used modified Bruce protocol.

Some studies have compared standard protocols and ramp protocols among various patient populations. ${ }^{27,29,30}$ Myers et al. showed that ramp protocols represented a higher correlation between $\mathrm{VO}_{2 \max }$ and the workload as compared to step protocols, thus reducing the forecast error as for the metabolic cost at various individual work- loads. ${ }^{26}$ But the results of other studies indicate that the peak cardiopulmonary responses as well as the accuracy of prediction $\mathrm{VO}_{2 \max }$ are similar in the individualized treadmill ramp protocols and step exercise protocols. ${ }^{27}$ The individualized ramp protocols are rather often used for exercise treadmill testing in older adults. ${ }^{23-25}$ However, studies concerning direct comparison of such protocols with traditional treadmill protocols among patients aged $\geq 70$ years are almost absent.

\section{CONCLUSION}

The individualized ramp treadmill protocol in patients aged 70 years and older allows the achievement of optimal test duration with higher degrees of workload and greater patient comfort during the test as compared to the modified Bruce protocol, thus suggesting its advantages and practicality for the routine clinical stress testing in the relevant age group.

\section{REFERENCES}

1. Ross R, Blair SN, Arena R, et al.; American Heart Association Physical Activity Committee of the Council on Lifestyle and Cardiometabolic Health; Council on Clinical Cardiology; Council on Epidemiology and Prevention; Council on Cardiovascular and Stroke Nursing; Council on Functional Genomics and Translational Biology; Stroke Council. Importance of Assessing Cardiorespiratory Fitness in Clinical Practice: A Case for Fitness as a Clinical Vital Sign: A Scientific Statement From the American Heart Association. Circulation 2016; 134(24): e653-e699.

2. Fletcher GF, Ades PA, Kligfield P, et al.; American Heart Association Exercise, Cardiac Rehabilitation, and Prevention Committee of the Council on Clinical Cardiology, Council on Nutrition, Physical Activity and Metabolism, Council on Cardiovascular and Stroke Nursing, and Council on Epidemiology and Prevention. Exercise Standards for Testing and Training. A Scientific Statement From the American Heart Association. Circulation 2013; 128(8): 873-934.

3. American College of Sports Medicine. ACSM's Guidelines for Exercise Testing and Prescription (8th edition). Philadelphia: Lippincott, Williams \& Wilkins; 2009. ISBN 9780781769037.

4. Balady GJ, Arena R, Sietsema K, et al.; American Heart Association Exercise, Cardiac Rehabilitation, and Prevention Committee of the Council on Clinical Cardiology; Council on Epidemiology and Prevention; Council on Peripheral Vascular Disease; Interdisciplinary Council on Quality of Care and Outcomes Research. Clinician's guide to cardiopulmonary exercise testing in adults: a scientific statement from the American Heart Association. Circulation 2010; 122(2):191-25.

5. Arena R, Myers J, Williams MA, et al.; American Heart Association Committee on Exercise, Rehabilitation, and Prevention of the Council on Clinical Cardiology; American Heart Association Council on Cardiovascular Nursing. Assessment of functional capacity in clinical and research settings: a scientific statement from the American Heart 
Association Committee on Exercise, Rehabilitation, and Prevention of the Council on Clinical Cardiology and the Council on Cardiovascular Nursing. Circulation 2007; 116(3): 329-43.

6. Forman DE, Arena R, Boxer R, et al.; American Heart Association Council on Clinical Cardiology; Council on Cardiovascular and Stroke Nursing; Council on Quality of Care and Outcomes Research; and Stroke Council. Prioritizing functional capacity as a principal end point for therapies oriented to older adults with cardiovascular disease: a scientific statement for healthcare professionals from the American Heart Association. Circulation 2017; 135(16): e894-e918.

7. Gill TM, DiPietro L, Krumholz HM. Role of exercise stress testing and safety monitoring for older persons starting an exercise program. JAMA 2000; 284(2): 342-9.

8. Myers J, Buchanan N, Smith D, et al. Individualized ramp treadmill. Observations on a new protocol. Chest 1992; 101(5 Suppl): 236S-41S

9. Myers J, Bellin D. Ramp exercise protocol for clinical and cardiopulmonary exercise testing. Sports Med 2000; 30: 23-9.

10. Porszasz J, Casaburi R, Somfay A, et al. A treadmill ramp protocol using simultaneous changes in speed and grade. Med Sci Sports Exerc 2003; 35(9): 1596-603.

11. Task Force Members, Montalescot G, Sechtem U, Achenbach S, et al. 2013 ESC guidelines on the management of stable coronary artery disease: the Task Force on the management of stable coronary artery disease of the European Society of Cardiology. Eur Heart J 2013; 34(38): 2949-3003.

12. Fox K, Garcia MA, Ardissino D, et al.; Task Force on the Management of Stable Angina Pectoris of the European Society of Cardiology; ESC Committee for Practice Guidelines (CPG). Guidelines on the management of stable angina pectoris: executive summary: The Task Force on the Management of Stable Angina Pectoris of the European Society of Cardiology. Eur Heart J 2006; 27(11): 1341-81.

13. Sadic J, Myers J, Froelicher V. A modified nomogram for ramp treadmill testing using the veterans specific activity questionnaire. Am J Cardiol 2014; 114(5): 803-5.

14. Wasserman K, Hansen JE, Sue DY, et al. Normal Values. In: Weinberg R. (ed.). Principles of Exercise Testing and Interpretation: Including Pathophysiology and Clinical Applications, 4th ed. Philadelphia: Lippincott Williams and Wilkins; 2005: 160-182.

15. Robergs RA. Simplified method and program for incremental exercise. protocol development. JEP online 2007; 10: 1-23.
16. Tanaka H, Monahan KD, Seals DR. Age-predicted maximal heart rate revisited. J Am Coll Cardiol 2001; 37(1): 153-6.

17. Foster C, Jackson AS, Pollock ML, et al. Generalized equations for predicting functional capacity from treadmill performance. Am Heart J 1984; 107(6): 1229-34.

18. Borg G. Borg's perceived exertion and pain scales. Publisher: Human Kinetics, 1998. ISBN: 0-88011-623-4.

19. Bourque JM, Beller GA. Value of Exercise ECG for Risk Stratification in Suspected or Known CAD in the Era of Advanced Imaging Technologies. JACC Cardiovasc Imaging 2015; 8(11): 1309-21.

20. Kokkinos P, Faselis C, Myers J, et al. Age-specific exercise capacity threshold for mortality risk assessment in male veterans. Circulation 2014; 130(8): 653-8.

21. Goraya TY, Jacobsen SJ, Pellikka PA, et al. Prognostic value of treadmill exercise testing in elderly persons. Ann Intern Med 2000; 132(11): 862-70.

22. Spin JM, Prakash M, Froelicher VF, et al. The prognostic value of exercise testing in elderly men. Am J Med 2002; 112(6): 453-9.

23. Lai S, Kaykha A, Yamazaki T, et al. Treadmill scores in elderly men. J Am Coll Cardiol 2004; 43(4): 606-15.

24. Faselis C, Doumas M, Pittaras A, et al. Exercise capacity and all-cause mortality in male veterans with hypertension aged $\geq 70$ years. Hypertension 2014; 64(1): 30-5.

25. Kokkinos P, Myers J, Faselis C, et al. Exercise capacity and mortality in older men: a 20-year follow-up study. Circulation 2010; 122(8): 790-7.

26. Myers J, Buchanan N, Walsh D, et al. Comparison of the ramp versus standard exercise protocols. J Am Coll Cardiol 1991; 17(6): 1334-42.

27. Bader DS, Maguire TE, Balady GJ. Comparison of ramp versus step protocols for exercise testing in patients $\geq 60$ years of age. Am J Cardiol 1999; 83(1): 11-4.

28. Kaminsky LA, Whaley MH. Evaluation of a new standardized ramp protocol: the BSU/Bruce Ramp protocol. J Cardiopulm Rehabil 1998; 18(6): 438-44.

29. Will PM, Walter JD. Exercise testing: improving performance with a ramped Bruce protocol. Am Heart J 1999; 138 (6 Pt 1): 1033-7.

30. Maeder M, Wolber T, Atefy R, et al. A nomogram to select the optimal treadmill ramp protocol in subjects with high exercise capacity: validation and comparison with the Bruce protocol. J Cardiopulm Rehabil. 2006;26:16-23. 


\title{
Пиковые ответы во время стресс-теста на беговой дорожке с использованием индивидуального Ramp- протокола и модифицированного протокола Bruce у пожилых пациентов
}

\author{
Сергей Козлов ${ }^{1}$, Мартин Капранда ${ }^{2}$, Ольга Чернова ${ }^{1}$, Марина Матвеева $^{1}$, Ирина Алексеева ${ }^{1}$, \\ Катарина Газдикова ${ }^{3}$, Лудовит Гаспар ${ }^{2}$, Петер Кружляк ${ }^{4}$, Славомира Филипова ${ }^{5}$, Зуфар \\ Габасов ${ }^{1}$ \\ ${ }^{1}$ Национальный медицинский исследовательский иентр, Министерство здравоохранения, Москва, Российская Федерация \\ ${ }^{2}$ Кафедра внутренних болезней, Медицинский факультет, Университет им. Коменского и университетская больница, Братислава, \\ Республика Словакия \\ ${ }^{3}$ Кафедра лечебного питания, Факультет сестринского дела и научньх исследований, Словацкий медицинский университет, Братислава, \\ Республика Словакия \\ 4 Лаборатория структурной биологии и протеомики, Университет ветеринарии и фармацевтических наук, Брно, Республика Чехия. \\ ${ }^{5}$ Отделение кардиологии, Национальный институт сердечно-сосудистых заболеваний и Словацкий медицинский университет, Братислава, \\ Республика Словакия
}

Адрес для корреспонденции: Петер Кружляк, Лаборатория структурной биологии и протеомики, Университет ветеринарии и фармацевтических наук, ул „Палкехо” № 1946/1, Брно 61242, Чехия; E-mail: peter.kruzliak@savba.sk; Teл.: +420543181111

Дата получения: 26 января 2019 Дата приемки: 18 июля $2019 \bullet$ Дата публикации: 31 марта 2020

Образец цитирования: Kozlov S, Caprnda M, Chernova O, Matveeva M, Alekseeva I, Gazdikova K, Gaspar L, Kruzliak P, Filipova S, Gabbasov Z. Peak responses during exercise treadmill testing using individualized ramp protocol and modified Bruce protocol in elderly patients. Folia Med (Plovdiv) 2020;62(1):76-81. doi: 10.3897/folmed.62.e49809.

\section{Абстракт}

Введение: Объём нагрузки является хорошо известным важным прогностическим фактором для пациентов с сердечно-сосудистыми заболеваниями и для здоровых людей.

Цель: Определить, существуют ли различия между реакцией на пиковую нагрузку, во время стресс-теста на беговой дорожке и модифицированным протоколом Брюса для пожилых пациентов.

Материалы и методы: В исследовании приняло участие 40 пациентов (как мужчин, так и женщин) в возрасте от 70 лет и старше, у которых не было исходного диагноза ишемической болезни сердца или сердечной недостаточности. Все пациенты проходили нагрузочный тест на беговой дорожке с применением модифицированного протокола Брюса и индивидуального Ramp-протокола в течение 2 дней подряд. В обоих тестах регистрировались пиковая частота сердечных сокращений, пиковое систолическое и диастолическое артериальное давление, пиковый двойной продукт (сердечный ритм х систолическое артериальное давление) (peak pressure-rate double product), продолжительность физической нагрузки и пиковые метаболические эквиваленты. Результирующий уровень упражнений оценивался по 10-балльной шкале Борга.

Результаты: Средняя продолжительность тренировки была продолжительнее для Ramp-протокола, чем для модифицированного протокола Брюса. Когда использовался модифицированный протокол Брюса, пациенты имели меньшую рабочую нагрузку, чем при применении Ramp-протокола. Оценка физической нагрузки по модифицированной шкале Борга (от 0 до 10) составила 5,6 $\pm 1,4$ для Ramp-протокола и 8,7 $\pm 1,4$ для модифицированного протокола Брюса, что свидетельствует о том, что пациенты воспринимают Ramp-протокол как более лёгкий.

Выводы: У пожилых пациентов индивидуальный Ramp-протокол на беговой дорожке позволяет достичь оптимальной продолжительности теста с более высокими уровнями нагрузки и с большим комфортом для пациента во время теста более часто, чем модифицированный протокол Брюса.

\section{Ключевые слова}

Пожилые люди, тестирование с физической нагрузкой на беговой дорожке, индивидуальный Ramp-протокол, модифицированный протокол Брюса, объём физической нагрузки 